OSOBA | DUSZA

Filozofia Chrzzé́ciJańsKa • Tom 7, Poznañ 2010

Uniwersytet im. Adama Mickiewicza - Wydziat Teologiczny

JAN GRZESZCZAK

Uniwersytet im. Adama Mickiewicza

Wydział Teologiczny

Zakład Filozofii Chrześcijańskiej

\title{
Awicenna wobec nieśmiertelności, preegzystencji i wędrówki dusz. Analiza De Anima, V, 3-4
}

Avicenna on Immortality, Pre-existence and the Transmigration of Souls.

The Analysis of De Anima, V, 3-4

Problem duszy u Awicenny (980-1037) domaga się kilku uwag wstępnych, porządkujących to zagadnienie. Ten wszechstronnie uzdolniony i niezwykle płodny autor, przykład średniowiecznego człowieka uniwersalnego, jest, obok Awerroesa, najbardziej znanym na Zachodzie przedstawicielem filozofii arabskiej. Jednakże już samo miejsce jego narodzin, czyli położone niedaleko Buchary miasto Afszan, kieruje naszą uwagę na geograficznie i etnicznie odległe od Półwyspu Arabskiego rubieże świata islamu i stąd znany arabista oraz iranista Henry Corbin zaproponował w latach sześćdziesiątych ubiegłego wieku odejście od powszechnie obowiązującego w podręcznikach historii filozofii terminu „filozofia arabska” i zastąpienie go określeniem „filozofia muzułmańska”, które nie zawęża filozofii islamu do tych powszechnie znanych myślicieli, których dzieła, tłumaczone na łacinę, były znane przedstawicielom średniowiecznej scholastyki ${ }^{1}$.

${ }^{1}$ Zob. H. Corbin, Historia filozofii muzułmańskiej, thum. K. Pachniak, Warszawa 2005, s. 711. Terminem „filozofia muzułmańska” posługuje się również Oliver Leaman, a Janusz Danecki we wprowadzeniu do swojego studium, noszącego tytuł: Arabowie, podkreśla istotną rolę, jaką w tworzeniu kultury Arabów odegrali Persowie, Berberowie, Kurdowie, Syryjczycy, chrześcijanie i Żydzi, a więc ludy nie związane bezpośrednio z Półwyspem Arabskim. Polski arabista przyjmuje za kryterium ,arabskości” wszystko to, co do końca wieku XIII rozwijało się pod panowaniem arabskich dynastii Umajjadów i Abbasydów, natomiast od wieku XIII za świat arabski uważa te obszary, które zajmuje on dzisiaj. Dlatego twórczość Awicenny jest dla Daneckiego przejawem kultury 
Na hellenizującą filozofię Arabów w wydaniu Awicenny i Awerroesa wpływ wywarł nie tylko islam, lecz także rozmaite czynniki zewnętrzne, takie jak teorie perskie, hinduska nirwana, a także wschodnia koncepcja Boga-Światła $^{2}$. Jej arystotelizm funkcjonuje $\mathrm{w}$ gruncie rzeczy $\mathrm{w}$ ramach neoplatońskich, czyli w koncepcji emanacji inteligencji z Boga, w której ustopniowaniu według doskonałości pomogła rozwinięta astronomia. Nie trzeba przypominać, że istotną rolę w refleksji autorów muzułmańskich odegrała święta księga islamu, czyli Koran, z którego zawartością usiłowano uzgodnić myśl filozoficzną. W tym bogatym ideowo i pełnym rozmaitych inspiracji kontekście pojawiła się refleksja Awicenny na temat duszy.

Awicenna poświęcił zagadnieniu duszy szóstą część swojej Księgi uzdrowienia (Kitab asz-Szifa), znaną w średniowiecznej Europie jako De Anima lub Liber Sextus de Naturalibus. Dzieło powstało najprawdopodobniej w czasie, gdy filozof przebywał w Hamadanie na terenie Iranu, gdzie tamtejszy władca Szams ad-Daula powierzył mu stanowisko wezyra. Trudności, jakie Awicenna napotkał w kontaktach z wojskowymi, spowodowały, że jego misja zakończyła się fiaskiem. Biograf i uczeń filozofa Al-Dżuzdżani twierdzi, że jego mistrz za dnia zajmował się polityką, a w nocy poważnymi sprawami, czyli nauką ${ }^{3}$. Prace nad Księga uzdrowienia rozpoczął krótko przed rokiem 1021, natomiast traktat o duszy powstał najprawdopodobniej w latach 1021-1024, jako część jego filozofii przyrody ${ }^{4}$.

De Anima Awicenny nie jest komentarzem czy parafrazą dzieła Stagiryty, lecz stanowi oryginalną syntezę nauki o duszy, utrzymaną w duchu perypatetyckim i neoplatońskim. Zachód zapoznał się z jej treścią głównie dzięki tłumaczeniu na język łaciński, dokonanemu w Toledo w latach 1152-1166. Po upadku Wizygotów miasto to znalazło się w rękach muzułmanów i stanowiło część al-Andalūs, czyli muzułmańskiej Hiszpanii. Zamieszkiwali je Arabowie, Żydzi i Mozarabowie, czyli chrześcijanie, którzy ulegli wpływom kultury arabskiej i przejęli język zdobywców. W roku 1085 król Kastylii i Leónu Alfons VI odbił Toledo z rąk Arabów, inaugurując w ten sposób nowy rozdział w dziejach miasta, które trzy lata później stało się siedzibą prymasa Hiszpanii i aktywnym centrum kultury. W XII wieku Toledo zasłynęło jako

\footnotetext{
arabskiej - zob. O. Leaman, Krótkie wprowadzenie do filozofii islamu, tłum. M. Lipszyc, Warszawa 2004; J. Danecki, Arabowie, Warszawa 2001, s. 13.

${ }^{2}$ Zob. S. Swieżawski, Dzieje europejskiej filozofii klasycznej, Warszawa-Wrocław 2000, s. 547.

${ }^{3}$ Zob. H. Corbin, Historia, s. 151.

${ }^{4}$ Zob. D.N. Hasse, Avicenna's ,De Anima” in the Latin West. The Formation of a Peripatetic
} Philosophy of the Soul 1160-1300 (Warburg Institute Studies and Texts, 1), London-Turin 2000, s. 1. 
siedziba szkoły thumaczy, działającej pod patronatem tamtejszych arcybiskupów. List poprzedzający tekst toledańskiego tłumaczenia dzieła Awicenny, w którym niejaki Avendeuth Israelita, Philosophus, zadedykował je arcybiskupowi Toledo Janowi, rzuca cenne światło na okoliczności jego powstania 5 .

Fakt, że Avendeuth przedstawia się jako tłumacz z języka arabskiego, działający z polecenia arcybiskupa, stanowił podstawę do sformułowania tezy, w myśl której za postacią tą stoi wykształcony w Kordobie XII-wieczny uczony żydowski Abraham Ibn Daud, który schronił się w Toledo przed prześladowaniami ze strony nietolerancyjnych władców arabskich z dynastii Almohadów i tam zmarł około roku $1180^{6}$. Avendeuth twierdzi, że thumaczenie jest wynikiem pracy zespołowej: on sam, mając przed oczyma arabski tekst Awicenny, wypowiadał poszczególne słowa w języku romańskim, którym posługiwali się mieszkańcy Toledo (singula verba vulgariter proferente), natomiast archidiakon Dominik Gundisalvi dokonywał ich tłumaczenia na łacinę (Dominico Archidiacono singula in latinum convertente) ${ }^{7}$. Do naszych czasów zachowało się pięćdziesiąt średniowiecznych rękopisów toledańskiego tłumaczenia, rozproszonych po archiwach i bibliotekach Państwa Watykańskiego, Włoch, Francji, Anglii, Niemiec, Belgii, Hiszpanii, Holandii, Szwajcarii, Szwecji i Chorwacji, co świadczy o tym, że spośród filozoficznych dzieł Awicenny jego traktat o duszy był najszerzej znany i studiowany przez ludzi średniowiecza.

Tak więc za bazę źródłową dla tego wystąpienia posłuży Avicenna Latinus, czyli łacińskie thumaczenie traktatu o duszy sporządzone przez Avendeutha i Gundisalviego. Oprócz informacji historycznych na temat okoliczności powstania tłumaczenia, list Avendeutha do arcybiskupa Toledo zawiera cenne, z punktu widzenia filozofii, wprowadzenie do problematyki traktatu Awicenny. Żydowski tłumacz rozpoczyna od stwierdzenia, że

choć każdy składa się z duszy i ciała, to jednak nie każdy posiada taką samą pewność co do duszy, jak co do ciała ${ }^{8}$. Ciało - kontynuuje Avendeuth - podlega dziedzinie zmysłów, a duszy dosięgamy tylko intelektem i stąd ludzie oddani zmysłom uważają że dusza jest niczym, a jeśli nawet zdarzy się, że wyczuwają jej istnienie na podstawie ruchu ciała, to większość z nich traktuje to, czym jest i jaka jest dusza, jako

${ }^{5}$ Zob. Avicenna Latinus, Liber de Anima seu Sextus De Naturalibus, I-III. Édition critique de la traduction latine médiévale, par S. Van Riet. Introduction sur la doctrine psychologique d'Avicenne, par G. Verbeke, Louvain-Leiden 1972, s. 3-6 (dalej cyt.: De Anima, I).

${ }^{6} \mathrm{Na}$ temat identyfikacji postaci Avendeutha z Abrahamem Ibn Daudem zob. D.N. Hasse, Avicenna's „De Anima” in the Latin West, s. 6-7; por. De Anima, s. 100-101.

${ }^{7}$ Zob. De Anima, I, s. 4.

${ }^{8}$ „Cum omnes constent ex anima et corpore, non omnes sic certi sunt de anima sicut de corpore" - De Anima, I, s. 3. 
przedmiot wiary, a niewielu przekonuje się drogą rozumowania. Jest zatem czymś niegodnym, by człowiek nie znał tej części siebie, poprzez którą poznaje, i nie uchwycił swoim rozumem tego, dzięki czemu jest rozumny. Jak więc może miłować siebie lub Boga, skoro jednocześnie okazuje się ignorantem w tym, co w nim samym najlepsze? ${ }^{9}$

Jak już wspomniano wyżej, traktat o duszy Awicenny stanowi oryginalną syntezę, inspirowaną dziełem Stagiryty. Z punktu widzenia filozofii Awicenna poddaje refleksję Arystotelesa interpretacji w duchu neoplatońskim, podkreślając zwłaszcza duchowy charakter duszy ludzkiej, jej nieśmiertelność oraz transcendencję intelektu czynnego. Nie bez znaczenia dla treści traktatu jest gruntowna wiedza medyczna arabskiego myśliciela. Ostatecznym rezultatem jego wysiłków jest dzieło, w którym ukazana przez Awicennę wizja człowieka, ma charakter bardziej duchowy niż ta, którą Arystoteles zawarł w swoim traktacie o duszy. Europa szybko dostrzegła nowość, widoczną w De Anima, i od XIII wieku przyjęła z życzliwym zainteresowaniem to dzieło, powstałe w innym niż chrześcijański kręgu kulturowym ${ }^{10}$.

Średniowiecze pozostawiło nam w spadku wiele traktatów opatrzonych tytułem: De Anima, z których duża część to komentarze dzieła Arystotelesa. Wgląd w ich zawartość pozwala stwierdzić, że najogólniej mówiąc, traktują o człowieku, jego zasadzie, władzach zmysłowych i intelekcie. Gerard Verbeke stawia w tym miejscu pytanie, czy nie byłoby w związku z tym bardziej słuszne pójście śladem Nemezjusza z Emezy, żyjącego na przełomie IV i V wieku autora dzieła De natura hominis, i mówienie o „traktacie o człowieku” zamiast o „traktacie o duszy”" . Czy Arystoteles, a za nim autorzy średniowieczni, stawia prosty znak równości pomiędzy człowiekiem i duszą, a w związku z tym nie bierze pod uwagę ciała? Jeśli człowiek identyfikuje się całkowicie z dusza, jakie znaczenie posiada w takim razie sam termin ,dusza”?

Choć De Anima Awicenny nie jest komentarzem do dzieła Stagiryty, to jednak podejmuje te same problemy, czyni to w tej samej, co arystotelesowska optyce i nawiązuje do przejętej przez Arabów tradycji perypatetyckiej. Nie można zrozumieć użytego przez Arystotelesa w tytule jego dzieła termi-

\footnotetext{
${ }^{9}$ „Quippe cum illud sensui subiaceat, ad hanc vero non nisi solus intellectus attingat. Unde homines sensui dediti, aut animam nihil esse credunt, aut si forte ex motu corporis eam esse coniiciunt, quid vel qualis sit plerique fide tenent, sed pauci ratione convincunt" - De Anima, I, s. 3.

${ }^{10}$ Zob. De Anima, I, s. 1*. Na temat recepcji dzieła Awicenny na chrześcijańskim Zachodzie zob. zwłaszcza: D.N. Hasse, Avicenna's „De Anima” in the Latin West, cyt.

${ }^{11}$ Zob. Avicenna Latinus, Liber de Anima seu Sextus de Naturalibus, IV-V. Édition critique de la traduction latine médiévale par $S$. Van Riet. Introduction sur la doctrine psychologique d'Avicenne par G. Verbeke, Louvain-Leiden 1968, s. 3* (dalej cyt. De Anima, II).
} 
nu $\psi v \chi \eta ́$, gdyby oznaczał on to, co pod tym pojęciem rozumiała tradycja homerycka $^{12}$. Stagiryta jest świadkiem daleko idącej ewolucji znaczenia pojęcia duszy. W czasach Sokratesa dokonała się radykalna transformacja w tym względzie i dla ateńskiego filozofa dusza nie była już materialnym tchnieniem, lecz zaczęła stanowić autentyczne centrum człowieka, zasadę poznania i działania moralnego. Jak twierdzi Gerard Verbeke,

Kiedy w drugiej połowie czwartego wieku przed Chrystusem Arystoteles pisze swój Traktat o duszy, ma już za sobą tradycję filozoficzną, a jego czytelnicy, znający myśl

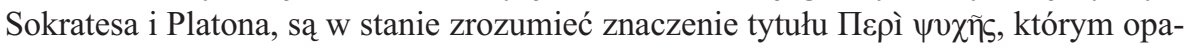
trzone zostało jedno z najczęściej studiowanych dzieł wchodzących w skład arystote-

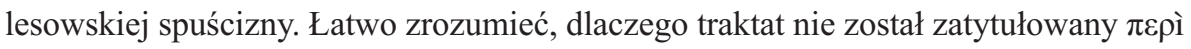
$\sigma \omega \mu \alpha \tau o \varsigma$. Chociaż Arystoteles nie podziela psychologicznego dualizmu Platona, to jednak prawdą jest, że jedność człowieka nie jest u niego tak daleko posunięta, jak we współczesnej fenomenologii. W swoich młodzieńczych dziełach i w Etyce nikomachejskiej Arystoteles nie waha się twierdzić, że człowiek to przede wszystkim i zasadniczo duch, choć uznaje też, że dusza jest aktem pierwszym ciała materialnego i organicznego, które posiada życie w możności. Zresztą, nawet jeśli nie uważa się ciała za anonimowe narzędzie, dane do dyspozycji «ja», nie oznacza to jeszcze, że ciało jest elementem konstytuującym całość człowieka: z wyjątkiem koncepcji czysto materialistycznej, zawsze będzie się uważać, że w człowieku istnieje wymiar przekraczający ludzką cielesność. Poza tym można również zrozumieć, dlaczego Stagiry-

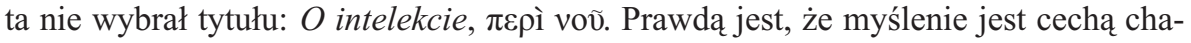
rakterystyczną człowieka, odróżniającą go od innych istot żywych, i grecki mistrz będzie to podkreślał: wiele rozdziałów Traktatu o duszy poświęconych jest studium myśli i, jeśli weźmiemy pod uwagę moralność Stagiryty i jego ideał kontemplacji jako element konstytutywny arystotelesowskiej eudajmonii, zdajemy sobie sprawę z wagi, jaką Arystoteles przywiązuje do intelektualnego wymiaru bytu człowieka. Myśl nie stanowi jednak całego człowieka, zwłaszcza gdy zdamy sobie sprawę z tego, że aktywność intelektualna tkwi korzeniami w doświadczeniu zmysłowym do tego stopnia, że w żadnym momencie nie można myśleć bez zmysłowego obrazu ${ }^{13}$.

Dzieło Arystotelesa jest więc traktatem o człowieku, a konkretnie studium formy substancjalnej bytu człowieka, która wpływa na ludzką cielesność. Badanie duszy oznacza jednocześnie studium ciała i wszystkich przejawów jego aktywności, począwszy od wegetatywnych, a skończywszy na myśleniu.

\footnotetext{
${ }^{12}$ Dusza jest dla Homera siłą zapewniającą człowiekowi życie, jest tchnieniem, które opuszcza go w momencie śmierci i dalej bytuje w świecie podziemnym.

${ }^{13}$ De Anima, II, s. 6*. „Gdy chodzi o duszę myśląca, wyobrażenia są dla niej prawie tym, czym [dla duszy zmysłowej] są postrzeżenia. Zależnie od tego, czy [za ich pomoca] uznała coś za dobre lub złe - czy nie uznała - ucieka przed nim lub dąży do niego. Dla tej to racji dusza nie myśli nigdy bez wyobrażenia" - Arystoteles, O duszy, III, 7, tłum. P. Siwek, w: tenże, Dzieła wszystkie, t. 3, Warszawa 2003, s. 133.
} 
Stagiryta staje w ten sposób u początków tradycji traktatów o duszy, a zagadnienia będące przedmiotem jego refleksji są integralną częścią filozoficznego spojrzenia na człowieka. Awicenna w pełni wpisuje się w ten zapoczątkowany przez niego nurt psychologii.

Przywołany wyżej list Avendeutha do arcybiskupa Toledo zawiera opis zawartości łacińskiego tłumaczenia dzieła Awicenny ${ }^{14}$. Tworzy je pięć ksiagg, poświęconych kolejno definicji duszy i klasyfikacji jej władz, duszy roślinnej, zmysłom zewnętrznym, zmysłom wewnętrznym oraz duszy rozumnej. Przedmiotem naszego wystapienia jest ukazana w trzecim i czwartym rozdziale księgi piątej argumentacja Awicenny za nieśmiertelnością duszy i przeciwko metempsychozie i preegzystencji ${ }^{15}$.

Konsekwentne opowiedzenie się za poglądami Platona i Arystotelesa nie pozostawia wątpliwości również co do związku pomiędzy preegzystencją duszy i jej nieśmiertelnością. Na początku VIII księgi Fizyki Stagiryta rozważa dwie ewentualności dotyczące ruchu: „czy ruch kiedyś powstał, nie istniejąc przedtem, i czy znów kiedyś przestanie istnieć, tak iż nic się nie będzie poruszać? Albo może nie powstał nigdy i nie przestanie istnieć, lecz zawsze był i zawsze będzie?" ". Filozof nie bierze pod uwage pozostałych dwóch hipotez, które można w tym przypadku sformułować, czyli ruchu, który miałby początek i trwał bez końca oraz ruchu bez początku, ale kończącego się w którymś momencie. Czyni tak dlatego, ponieważ dwie ostatnie hipotezy są przez niego odrzucone a priori: to, co zaczęło istnieć, jest w możności przestać być, ponieważ możność, która nigdy się nie urzeczywistnia, jest dla Arystotelesa nie do pomyślenia ${ }^{17}$. Szukając powodów tego typu podejścia, należy podkreślić, że widoczna u Stagiryty wizja świata wyklucza transcendencję i wolność stwórczą ${ }^{18}$. Przechodząc na teren rozważań o duszy, należy stwier-

\footnotetext{
${ }^{14}$ Zob. De Anima, I, s. 4-6.

15 „In quarto ostenditur quod anima humana non desinit esse nec transit ad alia corpora” - De Anima, I, s. 6; zob. De Anima, II, s. 113-126.

${ }^{16}$ Arystoteles, Fizyka, VIII, 1, thum. K. Leśniak, w: tenże, Dzieła wszystkie, t. 2, Warszawa 2003, s. 167.

${ }^{17}$ „Wszak to, co powstaje, musi mieć swój koniec, a to, co ginie - swój kres” - tamże, III, 4, s. 71; zob. tenże, O niebie, I, 10, tłum. P. Siwek, w: tenże, Dzieła wszystkie, t. 2, s. 261.

${ }^{18}$ „Zdanie, w myśl którego świat kiedyś powstał, lecz jest wieczny, jest niemożliwe do przyjęcia. W rzeczy samej rozum wymaga, abyśmy przyjmowali za prawdę tylko to, co widzimy realizowane obecnie w wielu lub we wszystkich przypadkach. Otóż w naszym konkretnym przypadku rzeczy mają się przeciwnie. Doświadczenie bowiem wykazuje, że wszystko, co powstaje, podlega zniszczeniu.

Ponadto rzecz, której stan obecny nie ma początku i która w swym całym uprzednim istnieniu nie mogła być w innym stanie, ta rzecz - mówię - nie może ulec zmianie. W przeciwnym razie musiałaby istnieć jakaś przyczyna wprowadzająca tę zmianę. Otóż gdyby ta przyczyna istniała
} 
dzić, że, w przeciwieństwie do Platona, Arystoteles odrzuca jej preegzystencję i związaną z nią teorię anamnezy. Tak więc - według Stagiryty - dusza, która nie istniała wiecznie, przestanie też istnieć. Scholastycy mieli świadomość trudności w pogodzeniu arystotelesowskiej doktryny z chrześcijańską nauką o nieśmiertelności duszy, a z kolei przywołany wyżej Nemezjusz z Emezy przyjął jej preegzystencję, aby ocalić nieśmiertelność ${ }^{19}$.

Awicenna przeciwstawia się preegzystencji duszy ludzkiej, ale opowiada się jednocześnie za jej nieśmiertelnością, zrywając $\mathrm{w}$ ten sposób z greckim przekonaniem, w myśl którego to, co zaczęło istnieć, nie może istnieć wiecznie $^{20}$. Argumentacja filozofa przeciwko preegzystencji wychodzi od stwierdzenia, że dusze ludzkie są tego samego rodzaju (unum sunt in specie et definitione). Gdyby jednak założyć, że istniały zanim połączyły się z ciałem, nie byłaby możliwa ich wielość, o której można mówić dopiero w przypadku zaistnienia różnicy (alteritas) ${ }^{21}$. Połączenie z ciałem jako materią sprawia, że można mówić o prawdziwej różnicy pomiędzy poszczególnymi duszami, opartej na uwarunkowaniach czasu i przestrzeni, i stąd niemożliwe jest, by dusze istniały zanim połączyły się z ciałem.

Kolejne założenie, z którym Awicenna rozprawia się w trzecim rozdziale księgi piątej traktatu De Anima, polegałoby na przyjęciu istnienia jednej duszy wiecznej (essentia eius sit una numero), która łączyłaby się z poszczególnymi ciałami ${ }^{22}$. Jest to jednak niemożliwe, ponieważ będąc niematerialną, jedna dusza nie mogłaby się dzielić, a co za tym idzie istnieć w dwóch różnych ciałach, a ponadto rozwiązanie takie prowadziłoby do negacji indywidualnego charakteru poszczególnych dusz ludzkich ${ }^{23}$.

wcześniej, wówczas rzecz, która nie była zdolna znaleźć się w stanie odmiennym od swego, byłaby do tego zdolna" - Arystoteles, O niebie, I, 10; zob. De Anima, II, s. 30*.

${ }^{19}$ Zob. De Anima, II, s. 30*-31*.

${ }^{20}$ „Dicemus autem quod anima humana non fuit prius existens per se et deinde venerit in corpus" - tamże, s. 105.

${ }^{21}$, ,...] si autem posuerimus quod prius habuerunt esse per se et non inceperunt cum corporibus, impossibile est tunc ut animae in ipso esse habeant multitudinem. Multitudo enim rerum aut est ex essentia et forma, aut est ex comparatione quae est ad materiam et originem multiplicatam ex locis quae circumdant unamquamque materiam secundum aliquid aut ex temporibus propriis uniuscuiusque illarum quae accidunt illis accidentibus, aut ex causis dividentibus illam. Inter animas autem non est alteritas in essentia et forma: forma enim earum una est" - tamże, s. 105-106.

${ }_{22}$ Zob. tamże, s. 107.

${ }^{23}$ „Dicemus etiam esse impossibile ut essentia eius sit una numero: cum enim fuerint duo corpora, acquirentur eis duae animae, quae duae aut erunt partes illius unius animae, et tunc aliquid quod non habet magnitudinem nec molem erit divisibile in potentia (huius autem destructio manifesta est ex principiis praepositis in naturalibus et in aliis), aut illa anima una numero erit in duobus corporibus, hoc etiam per se patet falsum esse" - tamże. 
Awicenna twierdzi, że indywidualny charakter dusz ludzkich jest ich przypadłością, która występuje wtedy, gdy pojawiają się ciała zdolne do tego, by im służyć (materia corporalis apta ad serviendum eis). Stworzone ciało jest - w myśl pięknego określenia filozofa - królestwem i narzędziem duszy (corpus creatum est regnum eius et instrumentum $)^{24}$. Wraz z pojawieniem się ciała dusza rozpoczyna właściwą jej aktywność, polegającą na zajmowaniu się nim, co sprawia również, że nie wykazuje pod tym względem zainteresowania pozostałymi ciałami ${ }^{25}$.

W czwartym rozdziale piątej księgi De Anima Awicenna podejmuje problem nieśmiertelności duszy, czyli jej trwania po śmierci ciała. Podstawą argumentacji za nieśmiertelnością duszy jest akcydentalny charakter jej związku z ciałem, który - jak widzieliśmy wyżej - decyduje o jej indywidualności $^{26}$. Filozof wychodzi od stwierdzenia, że w sytuacji, kiedy coś ulega zniszczeniu wraz ze zniszczeniem czegoś innego, to pierwsze musi zależeć w jakiś sposób (aliquo modo) od drugiego. Jako że związek duszy z ciałem ma charakter akcydentalny, a nie istotowy, zniszczenie ciała oznacza dla duszy zerwanie łączącej ją z nim relacji (destruetur relatio quae accidit alteri). Po śmierci ciała każda dusza zachowuje swój indywidualny charakter. Związek z ciałem daje duszy możliwość nabycia właściwych jej cech i przymiotów, które nie giną wraz ze śmiercią ${ }^{27}$. Na charakter nabytych przez duszę przymiotów ma wpływ zarówno samo ciało, jak i czas, w jakim dany człowiek żył na świecie. Tak więc miarę upływu życia ludzka egzystencja nabiera coraz bardziej indywidualnego charakteru w tym, co obejmuje myśl, poznanie samego siebie, a nawet cechy, których sobie nie uświadamiamy (proprietates nobis occultae $)^{28}$.

${ }^{24}$ Zob. tamże, s. 108.

${ }^{25},[\ldots]$ in substantia animae quae incipit esse cum aliquo corpore propter quod debuit creari ex primis principiis, inest affectio inclinationis naturalis ad occupandum se circa illud et ad regendum illud et providendum ei in omnibus et adhaerendum ei; et per haec omnia fit eius propria et alienatur ab aliis omnibus corporibus circa illud tantum" - tamże.

${ }^{26}$ Zob. De Anima, II, s. 114.

${ }^{27}$ „Dicemus [...] quod postea animae sine dubio sunt separatae a corporibus; prius autem unaquaeque habuerat esse et essentiam per se, propter diversitatem materiarum quas habebant et propter diversitatem temporis suae creationis et propter diversitatem affectionum suarum quas habebant secundum diversa corpora sua quae habebant" - tamże, s. 109-110.

${ }^{28}$ „Sed demonstrabimus quod anima, cum creatur cum creatione alicuius complexionis, possibile esse ut creetur post illam aliqua affectio in actionibus rationabilibus et in passionibus rationabilibus propter collectiones quarum differat ab actione quae est ei similis in alia; et ut affectio acquisita quae vocatur intellectus in affectu sit in una talis definitionis ut per eam differat ab alia anima; et quia accidit ei percipere essentiam suam singularem, quod habet ex eo quod percipit aliquam affectionem quae est eius propria et non alterius; possibile est etiam contingere in ea ex virtutibus corporalibus affectionem propriam quae pendeat ex affectionibus moralibus, aut sint ipsae eaedem, 
Wróćmy jednak do zależności pomiędzy ciałem i duszą w kontekście problemu zniszczenia ciała i konsekwencji, jakie niesie ono dla duszy. Awicenna uważa, że ciało nie jest przyczyną istnienia duszy i dlatego ta ostatnia istnieje nadal po śmierci. Związek ciało-dusza może mieć charakter równoczesnej koegzystencji, pierwszeństwa lub następstwa ${ }^{29}$. Jeśli ciało i dusza koegzystuja, a zachodzący pomiędzy nimi związek ma charakter istotowy, to substancją nie będzie ani jedno ani drugie, lecz obydwa ${ }^{30}$. Jeśli natomiast związek ten ma charakter akcydentalny, to rozkład jednego, nie spowoduje zniszczenia drugiego. Jeśli dusza czasowo poprzedzałaby ciało, to można przyjać, że zniszczenie ciała, które jest późniejsze, w żadnym wypadku nie spowodowałoby zniszczenia duszy. Jeśli natomiast dusza byłaby wobec ciała wcześniejsza istotowo (prius essentia), to ciało uległoby zniszczeniu tylko wraz ze zniszczeniem duszy. Tymczasem ciało niszczeje pod wpływem własnych czynników. Wynika stąd, że pomiędzy ciałem i duszą nie zachodzi związek o charakterze istotowym.

Pozostaje jeszcze Awicennie ewentualność, w której ciało jest wcześniejsze od duszy, a w takim przypadku byłoby ono przyczyną jej istnienia (corpus causa est esse animae), co logicznie pociagałoby za sobą rozkład duszy w momencie śmierci ${ }^{31}$. Nie jest jednak możliwa - zdaniem Awicenny - sytuacja, w której ciało byłoby przyczyną sprawczą, dającą duszy istnienie. Ciało jako takie działa i czyni coś tylko mocą którejś ze swoich władz, gdyby natomiast działało i czyniło coś jako takie, wówczas całe ciało wykonywałoby taką czynnośś ${ }^{32}$. Władze ciała mają zawsze charakter akcydentalny i materialny, i jako takie nie mogą dać istnienia substancji duchowej, jaką jest dusza.

aut ut sint ibi etiam aliae proprietates nobis occultae, quae consequuntur animas cum creantur et postquam creantur, qualia sequuntur singularia specierum corporalium, quibus differunt; et ut animae sint ita, sed differunt suis proprietatibus propter quas corpora creata fuerunt aut non, sive sciamus illas dispositiones sive non, aut aliquas illarum" - tamże, s. 111-113; zob. s. 33*.

${ }^{29}$ „Quod anima non moriatur in morte corporis ratio haec est: quia quicquid destruitur ad destructionem alterius, pendet ex eo aliquo modo. Sed quicquid pendet ex aliquo modo. Sed quicquid pendet ex aliquo, necesse est ut aut sit eo posterius aut sit eo prius essentia non tempore, aut habeat cum eo esse simul.. Si autem hoc est eis accidentale, non substantiale, tunc destructo uno illorum, destruetur relatio quae accidit alteri et non destruetur ad destructionem alterius, quamvis sic pendeat ex eo" - tamże, s. 113-114.

${ }^{30}$,Si autem anima sic pendet ex corpore sicut ex eo cum quo habet simul esse, et hoc fuerit ei essentiale, non accidentale, tunc uniuscuiusque eorum essentia relativa est ad alterum., et sic nec corpus nec anima est substantia; sed est utrumque substantia" - tamże.

${ }^{31}$ Zob. tamże, s. 118.

$32,,[\ldots]$ corpus enim ex hoc quod est corpus non agit aliquid; non enim facit nisi per virtutem: si enim ageret per seipsum et non per virtutes suas, tunc omne corpus ageret illam actionem" tamże, s. 115. 
Ciała nie można także traktować w kategoriach przyczyny receptywnej (causa recipiens), czyli w znaczeniu nadania mu formy przez duszę $e^{33}$. Awicenna podkreśla, że „ciało nie jest formowane formą rozumnej duszy” (corpus non est formatum forma animae rationalis) i precyzuje, że nie dokonuje się to ani poprzez złożenie (ad modum compositionis) ani w sposób prosty (ad modum simplicitatis). Ciało składa się z właściwych sobie licznych elementów i nie jest też, jak statua z brązu, która składa się z jednego elementu, jakim jest metal ${ }^{34}$. Dusza natomiast, jako rzeczywistość duchowa, nie może odgrywać roli czynnika formującego materię, rozumianą jako causa recipiens. Tym bardziej więc nie jest ciało przyczyną formalną duszy ${ }^{35}$.

Poprzez krytykę powyższych prób ukazania związku duszy z ciałem Awicenna chce podkreślić, że $\mathrm{w}$ żadnym przypadku ciało nie może być uznane za przyczynę istnienia duszy, a zatem śmierć ciała nie ma wpływu na jej dalsze istnienie. Można by przy tej okazji zapytać, czy nie jest możliwa sytuacja, w której dusza zostałaby stworzona bez ciała lub odwrotnie. Filozof udziela na to pytanie odpowiedzi negatywnej: dusza zaczyna istnieć wraz z ciałem, w którym zamieszkuje i czyni je swoim narzędziem, nie oznacza to jednak, że w momencie śmierci zniszczenie jednego pociąga za sobą zanik drugiego. Dusza jest całkowicie prosta (anima est simplex absolute), stąd też nie posiada aktu istnienia wraz z jednoczesną możnością tego, by przestać istnieć, jak w przypadku bytów składających się z materii i formy ${ }^{36}$. Aksjomatu, w myśl którego to, co ma początek istnienia, przestanie istnieć, nie można - zdaniem Awicenny - odnieść do duszy. W bytach będących złożeniem materii i formy materię cechuje zdolność zachowania (virtus permanendi) formy przy jednoczesnym występowaniu ewentualności rozkładu (virtus corrumpendi). Sytuacja taka nie ma miejsca w przypadku duszy ludzkiej, która jest niezniszczalna. Awicenna zaznacza, że do takich wniosków doszedł powodowany posłuszeństwem wobec Boga ${ }^{37}$.

33 „Impossibile est etiam corpus esse causam recipientem: iam enim probavimus et ostendimus quod anima non est impressa in corpore aliquo modo" - tamże.

${ }^{34}$ Zob. tamże, s. 34*.

35 „Impossibile est etiam corpus esse causam formalem animae aut perfectivam: melius est enim hoc esse e converso. Ergo non pendet anima ex corpore ut causatum a sua causa essentiali, quamvis complexio et corpus causae sint animae accidentales" - tamże, s. 115.

${ }^{36}$ „Manifestum est [...] quod in eo quod est simplex non compositum aut radix compositi, non conveniunt effectus permanendi et potentia destruendi comparatione suae essentiae: si enim fuerit in eo potentia destructionis, impossibile est esse in eo effectum permanendi; si autem fuerit in eo effectus permanendi et habuerit esse, tunc non est in eo potentia destruendi: ergo manifestum est quod in substantia animae non est potentia corrumpendi" - tamże, s. 122; zob. s. 121.

37 „Ergo ostensum est humanam animam non corrumpi ullo modo, et ad hoc perduximus nostrum verbum nutu divino" - zob. 124. Za pomocą wyrażenia nutu divino toledańscy thumacze przełożyli na łacinę arabskie sformułowanie: „Boga trzeba prosić o pomoc” - zob. tamże. 
Pozostaje nam jeszcze problem stosunku Awicenny do metempsychozy. Terminu tego próżno szukać w De Anima, natomiast filozof rozważa możliwość wystąpienia sytuacji, w której dusza mogłaby kolejno zamieszkiwać w wielu ciałach. W tym samym momencie, gdy pojawia się konkretne ciało zdolne przyjąc duszę, ta ostatnia zostaje stworzona dla niego. Gdyby więc założyć ewentualność, o której mowa, czyli wędrówkę duszy od jednego ciała do drugiego, mogłoby dojść do sytuacji, w której w jednym ciele znalazłyby się jednocześnie dwie dusze ${ }^{38}$. Tymczasem człowiek jest świadom tego, że posiada jedną duszę, która kieruje ciałem. Ewentualna obecność drugiej duszy byłaby czymś niedopuszczalnym, ponieważ ciało stanowiłoby dla niej element obcy ${ }^{39}$. Jednym z kluczowych punktów argumentacji Awicenny jest podkreślany często związek duszy z ciałem, wyrażający się poprzez jej troskę o ciało oraz poznanie i związane $\mathrm{z}$ nim cielesne uwarunkowania, mające wpływ na doskonalenie się duszy w ciagu życia człowieka. Nie oznacza to jednak, że dusza ludzka zależy od ciała, jak coś, co odciska się w nim (quasi impressa in eo). Taki sposób istnienia duszy w ciele widzimy - zdaniem Awicenny - u roślin i zwierząt: ich dusze są odciśnięte w materii, nieodłączne od niej, a co za tym idzie, śmiertelne. Duchowa płaszczyzna związku duszy ludzkiej z ciałem wskazuje na jej nieśmiertelność.

Sposób argumentacji, widoczny w De Anima Awicenny, cechuje dynamika, przypominająca bardziej żywy wykład niż przelane na papier refleksje. Łacińskie thumaczenie zachowuje tę cechę stylu filozofa, widoczną także w dziełach Stagiryty. Dynamiczna jest również sama koncepcja duszy, inspirowana właściwym dla neoplatonizmu napięciem pomiędzy tym, co cielesne i tym, co duchowe ${ }^{40}$. To sprawia, że jego psychologia ukazuje człowieka jako

${ }^{38}$, ,Si autem posuerimus quod una anima transfertur ad multa corpora, unicuique autem corpori per se debet anima creari quae pendeat ex ipso, tunc unum corpus habebit duas animas Samul" tamże, s. 125.

39 „Deinde non sic anima pendet ex corpore quasi impressa in eo, sicut iam saepe ostendimus, sed sic pendet ex eo sicut circa quod occupatur et cognoscit et quod patitur ex illa. Omne autem animal cognoscit et percipit animam suam unam esse quae est imperans et regens suum corpus quod habet; si autem est ibi alia anima quam non percipit animal, nec quae occupatur circa suum corpus, tunc non pendet ex illo corpore: non enim pendet anima ex corpore nisi hoc modo" - tamże.

${ }^{40}$ „Il est clair que cette conception dynamique de l'âme est d'inspiration néoplatonicienne: l'homme se trouve perpétuellement à la limite de deux mondes, l'intelligible et le sensible; il peut se porter vers l'un ou vers l'autre, vers le haut ou vers le bas. L'attitude d'Avicenne vis-à-vis des veleurs corporelles est loin d'être négative: c'est la tâche de la raison pratique de diriger les facultés corporelles. Il n'en reste pas moins vrai que la direction du monde corporel ne réalise pas l'idéal suprême de l'âme rationelle; celle-ci doit devenir de plus en plus ce qu'elle est, ,substance solitaire", capable d'exercer par elle même l'action qui lui est propre: la contemplation des premiers principes de tout ce qui est" - tąe, s. 46*. 
istotę naznaczoną dualizmem. Tendencję tę można zauważyć również w doborze źródeł: Awicenna korzysta z komentarzy do dzieł Arystotelesa, których autorzy opowiadali się za uzgodnieniem Stagiryty z Platonem ${ }^{41}$. Dualizm psychologii Awicenny widoczny jest zwłaszcza w podkreślanej wyżej jedności duszy, a nie jedności człowieka. Ten ostatni nie jest traktowany jako zasada autonomicznych działań, co jest konsekwencją braku refleksji na temat wolności woli. Wydaje się, że Awicenna opowiedział się w gruncie rzeczy za pewnego rodzaju powszechnym determinizmem, w którym niewielką rolę odgrywa pojęcie autonomii człowieka.

Jak już wspomniano wyżej, średniowiecze pozostawiło po sobie znaczną liczbę traktatów De anima. Wśród ich autorów figurują znani scholastycy tacy, jak Roland z Kremony, Wilhelm z Owernii, Jan z La Rochelle, Aleksander z Hales, Piotr Hiszpan, Albert Wielki i Tomasz z Akwinu ${ }^{42}$. Choć każdy z nich zna traktat Awicenny i w mniejszym lub większym stopniu wykorzystuje zawarte w nim rozwiązania problemów dotyczących duszy, to jednak Albert Wielki jest pod tym względem niekwestionowanym liderem. Wpływ Awicenny na jego dzieło widoczny jest przede wszystkim w jego wczesnej Summa de homine, powstałej w latach 1242-1243. Dominikański mistrz, piszący jako teolog, stawia Awicennę na równi z Arystotelesem, uznając obydwóch za najwybitniejszych filozofów. Traktat o duszy Stagiryty jest cytowany w De homine Alberta około 280 razy, natomiast De Anima Awicenny 230 razy $^{43}$. Albert Wielki przyczynił się w znacznym stopniu do upowszechnienia znajomości psychologii Awicenny w późnośredniowiecznej Europie. Tomasz z Akwinu różni się jednak od swojego mistrza w podejściu do perypatetyckiej psychologii. W Sententia libri de anima obiera za punkt wyjścia Arystotelesa, choć nie idzie dalej śladem dotychczasowej tradycji perypatetyckiej i nadaje swojej psychologii nowy kierunek ${ }^{44}$. Nie brak u Akwinaty elementów krytyki poglądów Awicenny, zwłaszcza w odniesieniu do jego wizji intelektu i poznania ${ }^{45}$.

Analizowane wyżej argumenty Awicenny za nieśmiertelnością duszy i przeciwko jej preegzystencji i metempsychozie znajdują swój odpowiednik

${ }^{41}$ Zob. tamże, s. 72*.

${ }^{42}$ Zob. D.N. Hasse, Avicenna's „De Anima” in the Latin West, s. 36-73.

${ }^{43}$ Zob. tamże, s. 62.

${ }^{44}$ Zob. tamże, s. 69-73.

${ }^{45}$ Zob tamże, s. 72. Krytyce Awicenny poświęcony jest, między innymi, cały rozdział 74 księgi drugiej Summy contra gentiles, gdzie Tomasz z Akwinu ustosunkowuje się do jego poglądu, w myśl którego formy poznawcze nie są zachowywane w intelekcie możnościowym - zob. Św. Tomasz z Akwinu, Summa contra gentiles. Prawda wiary chrześcijańskiej w dyskusji z poganami, innowiercami i bładzacymi, tłum. Z. Włodek, W. Zega, t. I, Poznań 2003, s. 476-481. 
w Tomaszowej refleksji, zawartej w Summie Teologii, I, q. $75^{46}$. W artykule szóstym Akwinata odpowiada na pytanie: „,czy dusza ludzka jest zniszczalna?", rozpoczynając od stwierdzenia, że

w dwojaki [...] sposób ulega coś zniszczeniu: samo przez się lub z przyczyny przypadłościowej. Ale byt samoistny nie może powstać lub ulec zniszczeniu z przyczyny przypadłościowej, tzn. dzięki temu, że coś innego powstaje lub niszczeje. W ten sam bowiem sposób przysługuje jakiejś rzeczy powstawanie i uleganie zniszczeniu, w jaki posiada ona istnienie, które nabywa przy powstawaniu i które traci przy zniszczeniu. Rzeczy więc, mające istnienie same przez się, mogą tylko same przez się powstać lub ulec zniszczeniu; byty natomiast niesamoistne, jak przypadłości i formy materialne, rozpoczynają i kończą swe bytowanie wraz z powstawaniem i zniszczeniem bytów złożonych, których są elementami ${ }^{47}$.

Jako że dusza ludzka jest formą samoistną, co Tomasz udowadnia w artykule 2 kwestii 75, nie może przestać istnieć ${ }^{48}$.

Kolejnym argumentem przemawiającym za nieśmiertelnością duszy ludzkiej jest właściwe każdemu bytowi naturalne pragnienie istnienia w odpowiadający mu sposób. Zmysły zdolne są do poznania ograniczonego miejscem i czasem, natomiast intelekt ujmuje istnienie w sposób oderwany, urzeczywistniające się w każdym czasie.

Stąd to wszelki byt obdarzony umysłem - konkluduje Akwinata - z natury swej pragnie istnieć zawsze (omne habens intellectum naturaliter desiderat esse semper). Pragnienie zaś naturalne nie może być próżne. Wszelka więc substancja obdarzona umysłem jest niezniszczalna ${ }^{49}$.

Odpowiedź na pytanie o to, czy dusza ludzka i anioł należą do tego samego gatunku, staje się dla Tomasza okazją do stwierdzenia, że

choć ciało nie należy do istoty duszy, w istocie duszy tkwi skłonność do połączenia się z ciałem (anima ex natura suae essentiae habet quod sit corpori unibilis) ${ }^{50}$.

$\mathrm{Na}$ koniec zapytajmy, gdzie tkwią różnice pomiędzy nauką o duszy u Awicenny i Tomasza z Akwinu. Stefan Swieżawski stwierdza jednoznacznie, że koncepcja duszy u Awicenny nie jest arystotelesowska ${ }^{51}$. Dusza w ro-

${ }^{46}$ Zob. Św. Tomasz z Akwinu, Traktat o człowieku (Summa teologii I, 75-89), tłum. S. Swieżawski, Kęty 1998, s. 22-56.

${ }^{47}$ Tamże, s. 48.

${ }^{48}$ Zob. tamże, s. 28-33.

${ }^{49}$ Tamże, s. 50.

${ }^{50}$ Tamże, s. 56.

${ }^{51}$ Zob. S. Swieżawski, Dzieje europejskiej filozofii klasycznej, s. 548. 
zumieniu arabskiego filozofa jest przede wszystkim doskonałą substancją duchową, niematerialną i nieśmiertelną. Warto w tym miejscu odwołać się do słynnego argumentu Awicenny, znanego jako „latający człowiek” i występującego dwa razy w jego traktacie o duszy ${ }^{52}$. Człowiek stworzony bezpośrednio jako dorosły, zawieszony w próżni z ramionami i nogami rozłożonymi na boki, tak aby żadna $\mathrm{z}$ kończyn nie stykała się $\mathrm{z}$ inną, i nie poddany żadnym czynnikom zewnętrznym, oddziałującym na jakikolwiek ze zmysłów, według Arystotelesa nie mógłby poznawać, ponieważ, zgodnie z założeniami jego empiryzmu genetycznego, na podstawie wyników doświadczenia zmysłowego intelekt drogą abstrakcji tworzy ogólne pojęcia ${ }^{53}$. Odpowiedź Awicenny oddala się od arystotelesowskiej perspektywy: człowiek ten, nawet jeśli byłby pozbawiony percepcji swojego własnego ciała, to jednak wiedziałby, że istnieje (tamen sciret se esse) ${ }^{54}$. Teza ta, budząca niewątpliwie skojarzenia z kartezjańskim cogito, prowadzi do następujących wniosków: Awicenna wydaje się przyjmować istnienie w człowieku wiedzy czysto intelektualnej, nie opartej na doświadczeniu zmysłowym, i traktuje części ludzkiego ciała, jak ubranie, okrywające ,ja”, z tą jednak różnica, że garderobę możemy zdjąć i dlatego nie ma ryzyka pomieszania jej z osoba, natomiast części ciała mogą zostać uznane za ,ja” z powodu przyzwyczajenia do ich bliskości ${ }^{55}$. Na pytanie o to, czym jest ,ja”, Awicenna odpowiada: „«ja» to dusza”, ${ }^{\circ}$. W ten spo-

52 ,Dicemus igitur quod aliquis ex nobis putare debet quasi subito creatus esset et perfectus, sed velato visu suo ne exteriora videret, et creatus esset sic quasi moveretur in aere in inani, ita ut eum non tangeret spissitudo aeris quam ipse sentire posset, et quasi essent disiuncta membra eius ita ut non concurrerent sibi nec contingerent sese. Deinde videat si affirmat esse suae essentiae: non enim dubitabit affirmare se esse, nec tamen affirmabit exteriora suorum membrorum, nec occulta suorum interiorum nec animum nec cerebrum, nec aliquid aliud extrinsecus, sed affirmabit se esse, cuius non affirmabit longitudinem nec latitudinem nec spissitudinem. Si autem, in illa hora, possibile esset ei imaginari manum aut alium membrum, non tamen imaginaretur illud esse partem sui nec necessarium suae essentiae" - De Anima, I, s. 36-37; por. De Anima, II, s. 162.

${ }^{53}$ Zob. S. Kowalczyk, Teoria poznania, Sandomierz 1997, s. 15.

${ }^{54}$ Zob. De Anima, II, s. 162.

${ }^{55}$ „Haec autem membra non sunt vere nisi sicut vestes; quae quia diu est quod adhaeserunt nobis, putavimus nos esse illa aut quod sunt sicut partes nostri; cum enim imaginamur nostras animas, non imaginamur eas nudas, sed imaginamur eas indutas corporibus, cuius rei causa est diuturnitas adherentiae; consuevimus autem exuere vestes et proiicere, quod omnino non consuevimus in membris: unde opinio quod membra sunt partes nostri, firmior est in nobis quam opinio quod vestes sint partes nostri” - tamże, s. 162-163. Na temat ewentualnego wpływu „latającego człowieka” Awicenny na kartezjańskie cogito - zob. D.N. Hasse, Avicenna 's „De Anima” in the Latin West, s. 80; De Anima, II, s. 37*-38*.

${ }^{56}$ „Si quis autem dixerit: „,nescis quia hoc anima est”, dicam me semper scire, et quia haec est intentio quam voco animam, sed fortassis nescio illam appellari animam; cum autem intellexero illud vocari animam, intelligam illud esse hoc, et quia ipsum est regens instrumenta moventia et apprehendentia: unde nescio quod illud ego sit anima, dum nesciero quid sit anima. Non est autem sic dispositio cordis aut cerebri. Intelligo enim quid sit cor vel cerebrum, sed non intelligo quod 
sób filozof oddala się od arystotelesowskiej perspektywy i przechodzi na pozycję dualizmu psychologicznego, do którego predysponuje go zresztą jego orientacja neoplatońska.

Dla Tomasza z Akwinu centralnym zagadnieniem antropologicznym jest jedność człowieka ${ }^{57}$. „Musimy w sposób konieczny powiedzieć - podkreśla Akwinata w artykule 1 kwestii 76 - że intelekt będący zasadą działalności umysłowej jest formą ciała ludzkiego" 58 . Swoim odważnym stwierdzeniem dystansuje się od platońskiego spojrzenia na związek duszy z ciałem jako coś wtórnego i przypadłościowego. Dla Tomasza z Akwinu oznaczało ono wyciagnięcie takich wniosków z arystotelesowskiej doktryny, które równały się zerwaniem z panującą również w XIII wieku orientacją platońską i neoplatońską. Można zatem stwierdzić, że w ten sposób Akwinata dystansuje się także od ujęć widocznych w De Anima Awicenny ${ }^{59}$. Ujęcia te dotyczą najbardziej płaszczyzny teoriopoznawczej, a zwłaszcza przyjętej przez Awicennę koncepcji intelektu czynnego, chociaż - jak zaznacza Dag Nikolaus Hasse nie jest to jedyna trudność, jaką Tomasz napotkał w spuściźnie arabskiego filozofa ${ }^{60}$. Akwinata jest przeciwny teorii władz duszy, która bazuje na fizjologii człowieka, i rzadko nawiązuje do dorobku średniowiecznej medycyny. Inaczej jest w przypadku Awicenny, który umieszcza zmysły wewnętrzne w konkretnych miejscach ludzkiego ciała. Zmysł wspólny, osąd, wyobraźnia, fantazja i pamięć zajmują obszary mózgu, które arabski filozof lokalizuje z biegłością doświadczonego anatoma ${ }^{61}$.

Étienne Gilson spogląda na psychologię Awicenny przez pryzmat jego poglądów na temat istoty, które, choć mają za punkt wyjścia arystotelesow-

ipsum sit ego; cum enim intelligo quod ipsa anima est principium motuum et apprehensionum quas habeo et finis earum ex his omnibus, cognosco quod aut ipsa verissime est ego, aut quod ipsa est ego regens hoc corpus; fortassis autem non possum modo percipere ego per se separatim, sine permixtione perceptionis quod est regens corpus et coniunctum corpori" - De Anima, II, s. 164-165.

${ }^{57}$ Zob. S. Swieżawski, Dzieje europejskiej filozofii klasycznej, s. 673.

${ }^{58}$, ,...] necesse est dicere quod intellectus, qui est intellectualis operationis principium, sit humani corporis forma" - Św. Tomasz z Akwinu, Traktat o czlowieku, s. 88.

59 „In view of Thomas critical attitude towards Avicenna, it may appear obvious why Thomas writes psychology which follows Aristotle rather than Avicenna. The reasons given by modern scholars can be summarized as follows: Thomas's theory of intellection is based on the Aristotelian principle that all natural knowledge in this life is grasped through particulars (or phantasms). He realizes that Avicenna's theory of the separate active intellect as the illuminating source of knowledge is similar to that of Plato and that it is, just like Augustine's, incompatible with his own doctrine. Hence he turns to Aristotle” - D.N. Hasse, Avicenna's „De Anima” in the Latin West, s. 70.

${ }^{60}$ Zob. tamże, s. 70-71.

${ }^{61}$ Zob. De Anima, II, s. 49*-52*. Więcej na temat Tomaszowego spojrzenia na psychologię Awicenny - zob. D. N. Hasse, Avicenna's „De Anima” in the Latin West, s. 71-73. 
skie ujęcia substancji, to jednak zmierzają w kierunku rozwiązań esencjalistycznych ${ }^{62}$. Awicenna wyróżnia trzy stany istoty: występuje ona najpierw jako sama w sobie, następnie w intelekcie i w poszczególnych rzeczach ${ }^{63}$. Arabski filozof ilustruje to stwierdzenie znanym przykładem definicji „końskości":

[...] sama końskość nie jest czymś [innym], jak tylko końskością (ipsa equinitas non est aliquid nisi equinitas tantum). Sama w sobie nie jest bowiem ani mnoga, ani jedna; ani bytująca $w$ tych [rzeczach] zmysłowo doznawalnych, ani w umyśle; ani też nie jest czymś z nich w możności lub w skutku, tak by się to mieściło $\mathrm{w}$ istocie końskości, lecz jest tylko końskością ${ }^{64}$.

Tak rozumianą istotę samą w sobie Awicenna uczynił przedmiotem metafizyki $^{65}$. Jak konkluduje Paweł Milcarek:

Awicenna sformułował swoje ujęcie istoty samej w sobie, aby zrozumieć powszechnik [...] odkrywszy odmienny od istoty byt istnienia (esse existentiae), przypisał istocie jej własny byt (esse essentiae). W ten sposób Awicenna otworzył drogę do esencjalizacji bytu o wiele głębszej, bardziej fundamentalnej niż [...] u Awerroesa ${ }^{66}$.

Istoty Awicenny tworzą odrębny świat, a ich przykładem jest dusza „latającego człowieka”, która, nawet jeśli nie doznaje żadnych bodźców zewnętrznych i wewnętrznych, to jednak jest w stanie poznawać samą siebie, myśleć i mieć świadomość tego, że myśli. Jej związek z ciałem nie jest tak ścisły, jak $\mathrm{u}$ Arystotelesa. Ze swej strony św. Tomasz z Akwinu w De ente et essentia dostrzega i akceptuje jego odkrycie różnicy istoty i istnienia, ale nie zgadza się z przypisywaniem istocie jej własnego „bytu”67.

${ }^{62}$, ,[...] substancję rozumie się zasadniczo dwojako: jest to ostateczne podłoże, którym jest to, czego nie przypisuje się już niczemu innemu, a po drugie byt jako coś konkretnego, co może być też oddzielone, to znaczy forma, czyli istota" - Arystoteles, Metafizyka, 1017b 23-26, thum. T. Żeleźnik, Lublin 1996, s. 248; zob. É. Gilson, La filosofia nel Medioevo. Dalle origini patristiche alla fine del XIV secolo, Firenze 1994, s. 424.

${ }^{63}$ Zob. É. Gilson, Byt i istota, thum. D. Eska, J. Nowak, Warszawa 2006, s. 92; P. Milcarek, Od istoty do istnienia. Tworzenie się metafizyki egzystencjalnej wewnatrz tacińskiej tradycji filozofii chrześcijańskiej, Warszawa 2008, s. 167.

${ }^{64}$ Zob. Avicenna, Metaphysica, V, 1 - cyt. za: P. Milcarek, Od istoty do istnienia, s. 165.

${ }^{65}$ „Przedmiotem metafizyki nie jest rzecz jednostkowa, ale byt absolutny jako taki” - Awicenna, Księga wiedzy, tłum. B. Składanek, Warszawa 1974, s. 77.

${ }^{66}$ Zob. P. Milcarek, Od istoty do istnienia, s. 200.

${ }^{67}$ Zob. tamże, s. 193-200. Warto jednakże zauważyć za É. Gilsonem, że dla Awicenny definicja istoty nie obejmuje jej istnienia, ponieważ ich połączenie dokonuje się w akcie stwórczym. Arabski filozof jest w ten sposób wyrazicielem doktryny kreacjonistycznej, czyli takiej, w której przyczyna istnienia bytu przygodnego jest w stosunku do niego całkowicie zewnętrzna, ponieważ należy jej szukać w Bogu. Św. Tomasz, podobnie jak inni teologowie chrześcijańscy, podziela ten 


\section{SUMMARY}

Written probably between 1021-1024 the treatise on soul, known as Liber de Anima or Liber Sextus de Naturalibus, is one of the most popular works of Avicenna in the Middle Ages. It constitutes an original synthesis of the science of the soul, maintained in the peripatetic and neoPlatonic spirit. In book V Avicenna opposes pre-existence and the transmigration of souls. He provides numerous arguments in favour of the immortality of the soul. In this way he breaks away from the typically Greek understanding of the problem of soul. The basis of argumentation for the immortality of the soul is its unity with the body treated as accident.

The treatise on soul was received with kindness and interest by scholastics, particularly by Albert the Great. It includes ideas characteristic for Avicenna ideas, for example the story about the Flying Man resembling Cartesian cogito.

\section{Key words:}

Avicenna, immortality of soul, metempsychosis, pre-existence of soul

punkt widzenia i dlatego nie na tym polega jego oryginalność. Jak precyzuje É. Gilson, „Zagadnienie polega $\mathrm{w}$ istocie na tym, czy w bycie, urzeczywistniającym się aktualnie dzięki swej przyczynie, należy ujmować istnienie oddzielnie od istoty, a nawet - wyrażając się ściślej - jako akt istoty. Wiemy [...], że taki właśnie jest pogląd św. Tomasza z Akwinu, ale czy głosił go już Awicenna? Wszystko wskazuje, iż należy w to wątpić” - É. Gilson, Byt i istota, s. 96-97. 